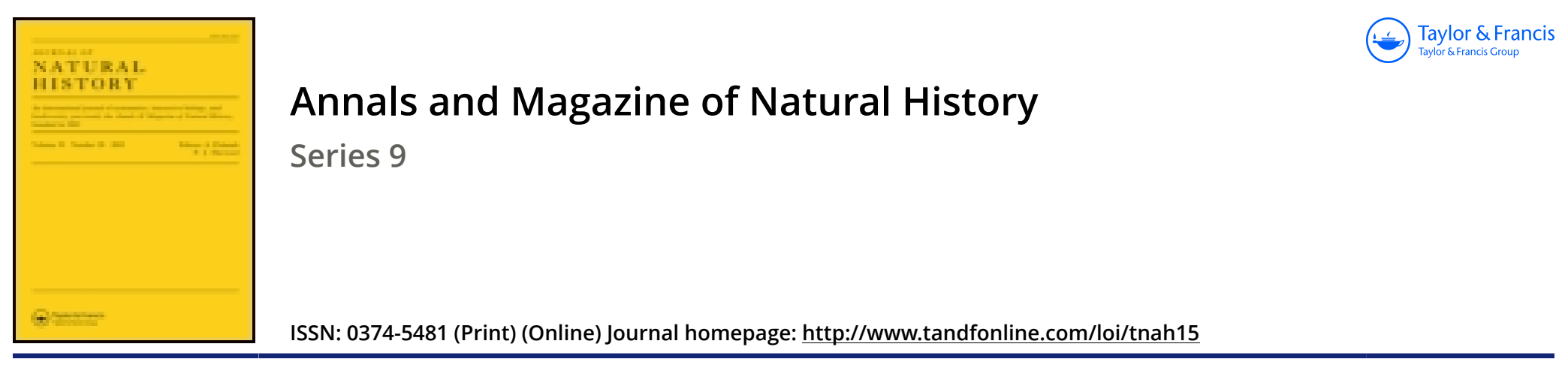

\title{
XXXIV.-On the arrangement of the small Tenrecidæ hitherto referred to Oryzorictes and Microgale
}

\section{Oldfield Thomas}

To cite this article: Oldfield Thomas (1918) XXXIV.-OOn the arrangement of the small Tenrecidæ hitherto referred to Oryzorictes and Microgale, Annals and Magazine of Natural History, 1:4, 302-307, DOI: 10.1080/00222931808562317

To link to this article: http://dx.doi.org/10.1080/00222931808562317

曲 Published online: 02 Sep 2009.

Submit your article to this journal $₫$

Џll Article views: 3

Q View related articles $₫$

4 Citing articles: 3 View citing articles 
posterior pararadial (Clark's "anal $x$ ") prevents the upward migration of the anal (Clark's "radinal") and inhibits its further growth, partly by drawing on its stereom for its own supply of calcium carbonate.

We may, therefore, continue to regard the anal in the Promachocrinidaes a homologous with that of the other comatulid larvae, and, in all, as the representative of anal $x$.

XXXIV.-On the Arrangement of the small T'enrecida hitherto referred to Oryzorictes and Microgale. By OLvFIELD THOMAs.

(Published by permission of the Trustees of the British Nuseum.)

There has long been some doubt as to the distinction from each other of the two genera Oryzorictes and Microgale, the latter of which I described in 1882, twelve years after Grandidier had described the former, and in consequence of this doubt the generic allocations used by Forsyth Major in describing the many new forms of Tenrec-sbrews which he discovered during his successful expedition of 1894-96 have never been revised or confirmed.

I have now had an opportunity of going over the Museum material of the group with a view to putting its generic arrangement more in order than it was left by Dr. Major, who never completed the admirable work he began on it. No additional specimens have been received since his collection came, but the fine series he obtained, combined with those previously collected by Mr. Deans Cowan and worked out by me, have enabled me to obtain some idea of the natural arrangement of the group.

I find that it may be divided into five genera, whose chief characteristics are set out in the following synopsis:-

A. Claws not markedly fossorial, the anterior not or little longer than the posterior. Canines not dominant, commonly low and bitid, and never surpassing the auterior incisors.

a. Molars with marked interual lobe. Incisors diminishing backwards, the canine considerably longer than $i^{3}$. Muzzle little elongated, the teeth touching each other. Fore-claws not longer than hind, 
$a^{2}$. Slcull hearily built. Interorbital region paraliel-sided. A high lambdoid crest present. Zygomatic process of squamosal prominent, projecting laterally beyond brain-case. Teth stout and heavy ; posterior secondury cusps reduced or absent

1. Nesogale, g. n.

$b^{2}$. Skull papery; tapering for wards evenly from the brain-case. Lambdoid crest not or scarcely developed, and not interrupting the smooth even profile of the skull. Zrimomatic process of squamosal minute, surpessed by the laternl inflation of the brain-case. Teeth light and delicate; posterior secondary cusps well developed ....

$b$. Internal basal lobe of molar's obsolete. Incisors subequal, the bicuspid canime little surpassing $i^{3}$. Murzle long and slender, the teeth widely spaced. Fore claws longer than lind ...............

B. Claws markedly fossorial, the third anterior

2. Microgale, Thos. twice the length of the third posterior. Canines dominant, al ways surpassing the anterior incisor; their secondary cusp quite small.

a. Pollex absent. Fur ordinary, Sliull less broadened behind ...............

b. Pollex present. Fur velvety, mole-like. skull more broadened behind ...... 5. Oryzorictes, Grand.

In the following notes the more important generic characters are not necessarily repeated, as they have been already given in the synopsis above:-

\section{Nesogale, $g . n$.}

Genotype. N. dobsoni (Microgale dobsoni, Thos.).

Other species :-talazaci, Maj.

A larger beavier form, related to Microgale, but with more powerful teeth and heavily ridged skull. In side view the skull is peculiar for the sinuosity of its profile, the high transverse occipital ridge being succeded anteriorly by a concavity, in front of which again there is a marked convexity whence the profile runs straight to the tip of the nasals, or is even slightly concave or sinuous. Below there is a marked ridge connecting the postglenoid processes with the entopterygoids, the ectopterygoids being practically obsolete.

Teeth essentially like those of Microgale, but stouter and 
heavier throughout, and the posterior basal cusp of the incisors and canines is reduced or absent. The anterior incisors are always longer than the canines.

A specimen in spirit of $N$. dobsoni, obtained by Dr. Major, has got an incrassated tail, but whether this is normal or seasonal I am not able to state.

\section{Microgale, Thos.}

Genotype. M. longicaulata, Thos.

Other described forms :-

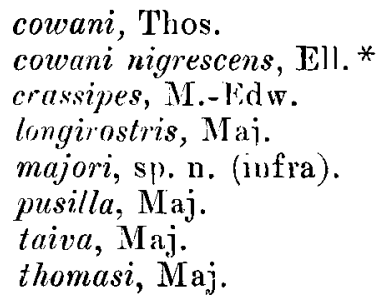

The characters of the teeth and the smoothly rounded profile of the skull, uninterrupted by any ridges or sinnosity, are sufficiently indicated in the figures in the original description + .

As noted below, the longer-tailed species, longicaudata and majori, have the tail modifier for prehension terminally, and the shorter-tailed forms, cowani and thomasi, not. But the intermediate-tailed taiva and pusilla are as intermediate in the structure as in the length of the tail, and show that no superspecific value can be attached to the modification.

The animal called $M$. c. nigrescens by Elliot is undoubtedly a mere melanism of a species which Dr. Major got in some numbers and which he referred to $M$. cowani. Several intermediate examples between the wholly brown and wholly black forms occur in our series, with a greater or less extent of the median dorsal area black.

But what its proper determination is still remains rather doubtful, as no less than three different points bearing on the question need further material for their elucidation. Firstly, what variation is found in typical M. cowani, for the type of that species differs in certain details of dentition

* P. Biol. Soc. Wash. xviii. p. 237 (1905).

† J. Linn. Soc., Zool. xvi. p. 319 (1882). 
from Dr. Major's "M. cowani." Secondly, what $M$. crassipes, M.-Edw., is-the measurements are not very different from those of Dr. Major's animal, though the claws would seem to be longer. And, thirdly, whether M. longirostris, Maj., is really different from his " $M$. cowani"; the hind foot of the type is certainly unusually long, but otherwise I can see no difference. On the whole, pending the arrival of further material, I am inclined to believe that the specimens called cowani by Major are not that species but are the same as his longirostris, of which, therefore, nigrescens would be a synonym. And crassipes may also possibly be the same animal.

The following new species was obtained by Mr. Deans Cowan with the first series of the genus, but was not then distinguished by me from $M$. longicaudata :-

\section{Microgale majori, sp. n.}

Allied to and of the same general proportions as $M$. longicaudata, but decidedly smaller and with less excessively long tail.

Length of skull and feet from 2-3 mm. less than in M. longicaudata. Colour, of a specimen skinned from spirit and therefore probably too rufous, reddish brown above and near " sayal-brown" below-but without specimens skinned fresh, these colours cannot be trusted ; bases of hairs everywhere dark slaty. Hands and feet brownish white. Tail very long, though not so long as in longicaudata, brown above, paler below.

Skull very similar in shape to that of $M$. longicaudata, but decidedly smaller. The brain-case is, however, rather more smoothly rounded, without such a marked inflation at the point where its greatest breadth occurs.

Dimensions of the type, those of the type of longicaudata in brackets :-

Head and body $60 \mathrm{~mm} .(67)$; tail 109 (158); hind foot $16(18 \cdot 2)$; ear $13(15)$.

Skull : greatest length 20.5 (22) ; condylo-basal length $19 \cdot 6(20 \cdot 9)$; greatest breadth across brain-case $9(\mathbf{9} \cdot \mathbf{6})$; palatal length $9^{\cdot 4}(10 \cdot 5)$; front of canine to back of $m^{3} 6 \cdot 8$ $(7 \cdot 4)$; combined length of $p^{4}-m^{2} 3 \cdot 1(3 \cdot 4)$.

Hab. Ankafina Forest, Eastern Betsileo.

Type. Adult female, skinued out of spirit. B.M. no. 82.3.1.17. Collected February, 1881, by the Rev. W. Deans Cowan. Thirty-seven specimens originally examined, 
of which, however, the majority were not retained for the Museum.

When I originally described Microgale longicaudata*, two of the specimens measured, one of them the type, stood out from the rest by their larger size and longer tails, but they were not thought to be specifically different until Dr. Forsyth Major, a few years ago, drew my attention to the possibility of two species being mixed up in the series. After the extraction of further skulls I find this suggestion to be correct, and now name the new species in honour of its first observer. The skull-measurements, however, given in the original description of longicaudata are those of a majori, and I therefore now publish for the first time those of the real longicaudata, taken from the type, no.82.3.1.15. The latter species is evidently much the rarer of the two, as only two specimens of it were collected by $\mathrm{Mr}$. Cowan as against thirty-seven of majori. An additional example of lonyicaudata was obtained by Dr. Major at Amboanara in 1896.

It may be of interest to record that these two long-tailed species of Microgale have the end of the tail for from half an inch to an inch naked and transversely wrinkled on its upper surface, just as in certain prehensile-tailed Muridæ. This character, and also the more lengthened fifth hind toe of the same species, indicates that these forms are arboreal, being the only Insectivora-other than the Tupaiidæwhich are so. Nor is any other truly prehensile tail known in the order.

\section{Leptogale, g. $\mathrm{n}$.}

Genotype. L. gracilis (Oryzoryctes gracilis, Maj.).

A remarkably slender-skulled form, with quite a number of special characteristics. The peculiar long narrow muzzle and small subequal widely spaced teeth, and the suppression in the molars of the prominent internal lobe so marked in other forms, render this one of the most isolated members of the group.

Dr. Major's brief preliminary account of it indicates that he appreciated its nearer relationship to Microgale than to Oryzorictes, and his use of the latter name was only due to his then thinking it possible that the two genera would grade into one another, and he therefore used the earlier

* J. Linn. Soc., Zool, xvi. p. 319 (1882). 
name. But that he later realized its peculiarity is proved by his having written on the typical skin a special generic name, no doubt intended for ultimate publication.

\section{Nesoryctes, g. n.}

Genotype. $N$. tetradactylus (Oryzoryctes tetradactylus, M.-Edw. \& Grand.).

No other species known, as O. niger, Maj., appears to me to be merely a melanism of $N$. tetradactylus.

Very like Oryzorictes in most respects, but not quite so highly modified for a fossorial life and with only four foreclaws. Its fur is like that of other members of the group, and not modified into the velvety condition of that of the Talpidæ, as is the case in Oryzorictes. The skull also is less markedly ridged and broadened behind than in that genus, nor is it so expanded at the tip of the muzzle.

No special differential characters in the teeth.

It may be here recorded that both Microgale cowani and Nesoryctes tetradactylus possess a baculum in the penis. The presence of this bone has been recorded in the larger Tenrecidæ, but no other Insectivores possess it.

The bone in Nesoryctes is a simple slightly curved spicule $6 \mathrm{~mm}$. in Iength, thickened at the proximal end.

5. Oryzorictes, M.-Edw.

Oryzoryctes, Trouess. (emend.).

Genotype and only species. O. hova, M.-Edw.

\section{XXXV.-The Baculum or $O_{s}$ Penis of some Genera of Mustelidæ. By R. I. Pocock, F.R.S.}

Mr. Oldfield Thomas's paper upon the os penis-or the baculum, as he appropriately names it-of the Sciuridæ shows that this bone, at least in the case of those rodents, has a quite unexpected value, greater than that supplied by the skulls and teeth, in determining the affinities of the genera. Very possibly it has a similar systematic importance in other groups of Mammalia, and deserves, in consequence, more attention than has hitherto been given to it by osteologists.

As has long been known, this bone is especially well developed in the Arctoid and Cynoid Carnivora. It has been 